\title{
Cancer preventing spices
}

\author{
Ishtiaque Alam', Hashmat Imam², Zarnigar Riaz² \\ ${ }^{\prime}$ Regional Research Institute of Unani Medicine, Patna 800008, Bihar, India. \\ ${ }^{2}$ Department of Preventive and Social Medicine, National Institute of Unani Medicine, Bengaluru 560091, Karnataka, India.
}

Correspondence to: Dr. Hashmat Imam, Department of Preventive and Social Medicine, National Institute of Unani Medicine, Kottigepalya,

Magadi Main Road, Bengaluru 560091, Karnataka, India. E-mail: mdhashmatimam@gmail.com

Sir,

Cancer is a major burden of disease worldwide not only in developed countries, but also in developing countries. ${ }^{[1]}$ Jemal et $a l^{[2]}$ have reported that about 12.7 million cancer cases and 7.6 million cancer deaths are estimated to have occurred in 2008 worldwide, in which $56 \%$ of the cases and $64 \%$ of the deaths were in the economically developing world. Moreover, the WHO has published that deaths from cancer worldwide are projected to continue to rise to over 12 million in 2030. ${ }^{[3]}$

Whether we have a history of cancer in our family or are currently battling the disease, lifestyle factors, including our diet, can make a huge difference in helping fight off cancer. Ongoing research supports the hypothesis that some foods actually increase our risk of cancer, while others may reduce cancer risk by a variety of mechanisms. These include a number of traditional spices that contain compounds with chemopreventive properties. Some common Indian spices with cancer-fighting properties are turmeric (Curcuma amada), black pepper (Piper nigrum), cardamom (Amomum aromaticum), cinnamon (Cinnamomum zeylanicum), clove (Syzygium aromaticum), garlic (Allium sativum), ginger (Zingiber officinale), cumin (Cuminum cyminum), saffron (Crocus sativus), coriander (Coriandrum sativum), dill (Anethum graveolens), basil (Ocimum basilicum), caraway (Carum carvi) ${ }^{\left[{ }^{[4}\right.}$ Active constituents are listed in Table $1^{[5]}$

To date, hundreds of compounds have been identified as potential cancer modifiers, several of which are active ingredients in above mentioned spices such as curcumin in turmeric, piperine in black pepper. ${ }^{[6,7]}$ Despite a rapidly growing body of experimental evidence supporting the cancer preventive properties of spices, minimal data exist regarding actual dietary intake levels of spices and the pharmacokinetics of active components. Today,

\begin{tabular}{|l|l|}
\hline \multicolumn{2}{|c|}{ Access this article online } \\
\hline Quick Response Code: & Website: \\
\hline & www.jcmtjournal.com \\
\cline { 2 - 2 } & \\
\hline
\end{tabular}

Table 1: Plants with anti-cancer activity

\begin{tabular}{lll}
\hline Plant name/family & Active constituent & Class \\
\hline Zingiber officinalel & $\begin{array}{l}\text { Gingerenone A, } \\
\text { Gingerols, shogaols, } \\
\text { zingerone }\end{array}$ & Curcuminoids \\
$\begin{array}{l}\text { Allium } \\
\text { sativum/Liliaceae } \\
\text { alliin, allicin } \\
\text { S-allylinase, } \\
\text { diallyl disulfide }\end{array}$ & Flavonoids \\
$\begin{array}{l}\text { Turcuma amada } \\
\text { Tinn./Zinziberaceae } \\
\text { Ocimum basilum } \\
\text { Linn./Laminaceae }\end{array}$ & $\begin{array}{l}\text { Eugenol, orientin, } \\
\text { and vicenin }\end{array}$ & $\begin{array}{l}\text { Volatile oil, } \\
\text { flavonoids, } \\
\text { phenolic compounds }\end{array}$ \\
\hline
\end{tabular}

spices are increasingly appreciated not only for their culinary properties but also for their potential health benefits. For some spices, health attributes associated with spice use may arise from their antioxidant properties. In other cases, the biological effects of spices may arise from their ability to modulate a number of cellular processes, including those involved with drug metabolism, cell division, apoptosis, differentiation, and immunocompetence. ${ }^{[6]}$

Spices can potentially inhibit the bioactivation of carcinogens, decrease free radical formation, suppress cell division and promote apoptosis in cancerous cells, regulate inflammation, and suppress microbial growth. The low toxicity may make them particularly useful as a subtle personal dietary change that may decrease the risk for several diseases. The addition of about $1 \mathrm{~g} /$ day of herbs to one's diet can significantly provide to total antioxidant intake $(>1 \mathrm{mmol}) \cdot{ }^{[8]}$ Because several spices are effective antioxidants, they may be particularly important in decreasing oxidative damage due to environmental stress, including excess calorie intake. ${ }^{[9]}$ Spices can be added directly to foods, as has been done historically, or used as dietary supplements.

To conclude, the potential chemopreventive properties of common spices deserve further, rigorous investigation in preclinical and clinical studies. There is considerable ongoing research on the pharmacological properties of individual compounds extracted from spices or herbal supplements (e.g. curcumin, resveratrol). However, basic and preclinical research on these compounds has been hampered 
by poor bioavailability and pleiotropic mechanisms of action that are difficult to study in traditional "one compound-one molecular target" experiments. It should be pointed out that natural products like spices contain complex mixtures of compounds that can affect each other's pharmacokinetics, solubility and potentially, pharmacodynamics. Future studies should take the complexity of natural products into account and use "systems biology" approaches to dissect their pleiotropic pharmacological properties.

\section{References}

1. Khambete N, Kumar R. Carcinogens and cancer preventors in diet. Int J Nutr Pharmacol Neurol Dis 2014;4:4-10.

2. Jemal A, Bray F, Center MM, Ferlay J, Ward E, Forman D. Global cancer statistics. CA Cancer J Clin 2011;61:69-90.

3. Bernardo RM, Monteiro MO, Mendes EC, Vicentini SC, Pinto NS, Paiva DN, Santos-Filho SD, Bernardo-Filho M. Cancer, prevention, research and the "calendar girls". Glob Adv Res J Med Med Sci 2012;1:266-9.

4. Mitra I. 8 Indian spices that prevent cancer. Available from: http://www.timesofindia.indiatimes.com/life-style/health-fitness/ $\operatorname{diet} / 8$-Indian-spices-that-prevent-cancer/articleshow/14863731. cms. [Last accessed on 2015 Mar 04].

5. Chavan SS, Damale MG, Shamkuwar PB, Pawar DP. Traditional medicinal plants for anticancer activity. Int J Curr Pharm Res 2013;5:50-4.

6. Kaefer CM, Milner JA. The role of herbs and spices in cancer prevention. J Nutr Biochem 2008;19:347-61.

7. Aggarwal BB, Kunnumakkara AB, Harikumar KB, Tharakan ST, Sung B, Anand P. Potential of spice-derived phytochemicals for cancer prevention. Planta Med 2008;74:1560-9.

8. Dragland S, Senoo H, Wake K, Holte K, Blomhoff R. Several culinary and medicinal herbs are important sources of dietary antioxidants. J Nutr 2003;133:1286-90.

9. Kaefer CM, Milner JA. Herbs and spices in cancer prevention and treatment. In: Benzie IF, Wachtel-Galor S, editors. Herbal Medicine: Biomolecular and Clinical Aspects. 2nd ed. Boca Raton (FL): CRC Press; 2011. p. 363-5.

How to cite this article: Alam I, Imam H, Riaz Z. Cancer preventing spices. J Cancer Metastasis Treat 2015;1:41-2.

Received: 04-01-2015; Accepted: 09-03-2015.

Source of Support: Nil, Conflict of Interest: None declared. 